\title{
Manufacturing Output and Labour Productivity: Evidence from ECOWAS
}

\author{
Adeyemi A. Ogundipe \\ Favour O. Olarewaju \\ Department of Economics and Development Studies, \\ Covenant University, Ota, Nigeria
}

DOI: https://doi.org/10.36941/ajis-2020-0o89

Abstract

The manufacturing sector is one growth enhancing, yet grossly neglected by many resource rich economies in Africa. It is adjudged critical to Africa economies due to its capacity to generate growth, accumulate wealth and tighten the inequality gap. The sector has been growing at a relatively slow rate, particularly due to the occurrence of four extreme inter-connected external shocks: fall in commodity (particularly oil) prices, global economic and financial crisis, and rise in energy and food prices which have worsened regional output and productivity levels. More importantly, the human capital component seems to be one major hindrance. To this effect, human capital channel is examined in this present re-examination. A static panel regression analysis was used to examine the effect of labour (controlled for technology) on manufacturing sector performance in ECOWAS region from 1990 to 2019. The study found that on the average, when controlled for technology, labour productivity significantly influence manufacturing sector in ECOWAS. Specifically, the availability of secure internet servers and individuals' internet usage were more important and positively stimulate the influence of labour productivity on manufacturing output in the region.

Keywords: Manufacturing output, Labour productivity, Technology, ECOWAS

\section{Introduction}

The emerging new growth theories place emphasize on domestic sufficiency arising from conscious development of the industrial sector of developing economies. Not very many nations, if any at all, have been able to build wealth and develop without adequate investment in the manufacturing sector - which tends to be export-oriented and labour-intensive at the early stages (Szirmai 2009; Afolabi \& Laseinde 2020). This gives way for industrialisation support, hence expanding value addition to commodities. The manufacturing sector has potentials for greater sustainability and is less susceptible to external shocks due to its ability to enhance productivity, inclusiveness and more dynamic than other sectors, especially as it appears to have peculiar opportunities for capital accumulation, economies of scale, spill-over effects, linkages and technological expansion (Ogundipe and Ola-David 2015). The over-arching concentration on limited exportable goods (mostly commodities) results in intense social and economic consequences leading to lesser resilience and higher regional vulnerability, which buttresses the need for diversified production and structural resilience (UNIDO, 2015; Anyanwu, 2018, 2017).

West African productivity grew by an annual average of 3.1\% between 2005 and 2016, reaching its peak of $8.7 \%$ in 2010. Nonetheless, this growth was majorly within-sector and dominated by agriculture 
and services. Contrarily, between-sector transformation was negative from 2005 to 2007 , positive between 2008 and 2014, and nearly non-existent in 2015 and 2016. Such marginal industrial betweensector growth was due to inability to turn comparative edge into comparative advantage, which is needed to boost manufacturing value-added (MVA from now) (West Africa Economic Outlook, 2018).

Most prior studies have focused on the relationship between manufacturing growth and economic growth (Tsoku, Mosikari, Xaba \& Modise, 2017; Meyer \& McCamel, 2017; Cantore, Clara, Lavopa \& Soare, (2017). Other prominent works also focused on how manufacturing growth has been impact by terms of trade (Delivani, 1992), structural change (De Vries, Timmer \& De Vries, 2015; Nattrass \& Seekings, 2012), industrial strategies (Rosendahl, 2010); comparative advantage (Sejkora \& Sankot, 2017); real wages (in relation to productivity growth) and employment (Asaleye, Olurinola, Oloni \& Ogunjobi, 2017). More so, recent empirical analyses centred on the determinants of capacity utilisation in Nigerian manufacturing (Adeyemi \& Olufemi, 2016) and how fluctuations in macroeconomic factors impact manufacturing sector output (Onakoya, 2018). However, this present assessment contributes to existing discourse by assessing the magnitude and direction of labour productivity on the manufacturing sector of ECOWAS countries using panel data analysis from 1990 to 2019.

Additionally, this paper differs from the extant literature by controlling for the effect of technology in the labour productivity and manufacturing output nexus in ECOWAS. The study provides relevant policy recommendations to ECOWAS economies in their attempt to adequately address the prevalent challenges of dwindling manufacturing value-added and enhance the productivity of labour by embracing technology. This study is also vital as it relates to the Sustainable Development Goal (SDG) 9 of Industry, innovation and Infrastructure. Specifically, target 9.2 encourages inclusive and sustainable industrialisation, in a bid to boost gross domestic product (GDP) and industrial share of employment in the least developed countries (LDCs) by 2030. Additionally, target 9.5 is concerned with upgrading scientific research, technological capacities as well as raising the volume of research and development (R\&D) workers (per 1 million people) across global industrial sectors, especially LDCs. Thus, these goals reinforce the need to build resilient infrastructure, promote sustainable industrialisation and foster innovation.

The rest of this paper is structured as follows: section two highlights relevant insights from literature. Section three presents the methodological framework and the empirical model. Section 4 presents the data, results and discussion while the last section concludes and proffers policy implications arising from the empirical findings.

\section{Review of Related Literature}

ECOWAS was established on May 28th 1975 by the Treaty of Lagos at Lagos, Nigeria. Its goals include a court of justice, social and economic councils, creation of West African parliament, single currency and a common economic market. Fifty (15) member countries exist in ECOWAS and are segmented into three official state languages: nine French speaking (Togo, Senegal, Niger, Mali, Guinea Bissau, Guinea, Ivory Coast/Côte d'Ivoire, Burkina Faso and Benin); five English speaking (Sierra Leone, Nigeria, Liberia, Gambia and Ghana), and Portuguese-speaking, Cape Verde, which joined in 1977.

The Mining, industry and manufacturing sectors in ECOWAS jointly contributed about $16.5 \%$ to her GDP. This shows the nature of manufacturing activities in West African economies; often characterised with marginal increases and steady decline. Hence, manufacturing development in the region has not gained significant attention (Anyanwu, 2018). The weak industrial base could be linked to high transaction costs and low infrastructural qualities. However, regional reforms have concentrated on price competitiveness, while non-price factors such as quality, institutions, technological innovations, distribution and marketing skills as well as timeliness are also very essential to boost industrial base and effectively penetrate international markets (Adenikinju \& Alaba, 2005; Agenor, 1995).

Keho (2018) investigated manufacturing's impact on the economic growth of eleven (11) ECOWAS nations from 1970 to 2014 using panel ARDL and causality tests. He found that economic advancement 
has positive impact on the manufacturing sector. Thus, the evidence suggest that structural transformation was proffered to foster industrial activities and production in ECOWAS. Concerning technology, Ossadzifo (2018) examined the evolution of mobile telephone subscription in ECOWAS from 2011 to 2016 and found that on the average, it enhances economic productivity. Though, the response rate is rather sluggish compared to other developed countries. The study by Rispal (2009) corroborates the evidence, suggesting that technology exerts a significant and positive impact on the economy. On the other hand, Solow (1987) suggested a non-effect of ICT on labour productivity. However, Capirossi (2002) analysed Solow's paradox and confirmed its non-correctness given the fact that the measurement tool chosen majorly influenced the paradox. It was noted that value added does not precisely capture technological influences on profitability, hence reflecting its exogeneity.

Bigsten (2000) explored how the aggregate years of education of manufacturing enterprise workers impacted sectoral productivity, thereby depicting the significant and positive influence of education in Kenya's manufacturing sector while the reverse applies for Zimbabwe, Zambia, Ghana and Cameroon. Somewhat similarly, Amin \& Mattoo (2008) discover positive and significant effect of human capital enrolment on overall and registered MVA without adding controls. Regardless, these results were not robust enough to accommodate control variables. Isaksson (2010) assessed the connection among infrastructure, physical capital and industrial advancement and confirmed the economic significance of human capital to manufacturing per capita. Similarly, Adejumo (2013) adopted autoregressive distributed lag (ARDL) technique to examine the link between ICT, education and MVA in Nigeria from 1970 to 2009 and established a significant relations between human capital and MVA growth.

Anyanwu \& Kponnou (2017) found a significant U-shaped relationship between education and industrial progress. At disaggregated level, an inverted U-shaped relationship occurred with chemical MVA, though positive connection was apparent with apparel/textiles MVA. On the other hand, secondary education had U-shaped association with chemical MVA although it was positively related with machineries and negatively linked with beverages, food, tobacco and other manufacturing industries. Notwithstanding, strong non-monotonic, inverted U-shaped relationship is found among tobacco, beverages and food; clothing and textiles; and other manufacturing enterprises with tertiary education. Nonetheless, tertiary education is positively associated with machineries, clothes/textiles and other manufacturing sectors whereas negative linkage is existent for chemicals and food, beverages and tobacco MVA.

\section{Methodology}

\subsection{Analytical Framework}

This study adapts the schematic illustration by Anyanwu (2018) for the education-manufacturing linkage. Primary education provides unskilled labour for basic manufacturing. The secondary education enables greater production dexterity; and tertiary education enriches manufacturing industries with superior levels of $\mathrm{R} \& \mathrm{D}$ as well as technological capabilities needed for complex production operations. The figure 1 shows how labour productivity via quality investment in education transmits to manufacturing output.

Following the concept of Becker (1998), human capital comprises health, education and on-thejob trainings, and these are basic requirements to enhance individuals' productivity. These three constituents compose the static and dynamic education effect. Workers' education (static) effect refers to productive values of education (Welch, 1970) which raises output per unit of schooling while the dynamic (allocative) educational effect results from augmenting human capital (Bartel \& Lichtenberg, 1987; Schultz, 1975). This entails allocative expertise being improved by training and learning as higher-educated people are better skilled to capitalise on up-to-date production avenues or modify existent methods to suit contemporary market trends compared to poorly educated and inexperienced personnel. Hence, such effectiveness emanates into greater quality commodities or lower prices. This human capital theory negates the screening hypothesis which attests that 
education does not enhance a person's productivity but rather implicitly separates low-productive people from the highly productive ones and classifies them into befitting jobs.

Regardless, more empirical evidence exists for human capital relative to screening hypothesis as it has been proven that human resources impacts manufacturing output and overall growth via several mediums. More interesting is the argument that high human capital engenders technology implementation based on the contention that skilled-labour augmented with technologies trigger productive gains unlike that of unskilled counterparts (Caselli \& Coleman, 2006; Benhabib \& Spiegel, 2005, 1994; Acemoglu, 2003). This is supported by neoclassical theories of international specialisation which considers human capital to be a production input, thereby propagating rigorous schooling for human-capital-related industries (Ciccone \& Papaioannou, 2009; Nunn, 2007; Levchenko, 2007).

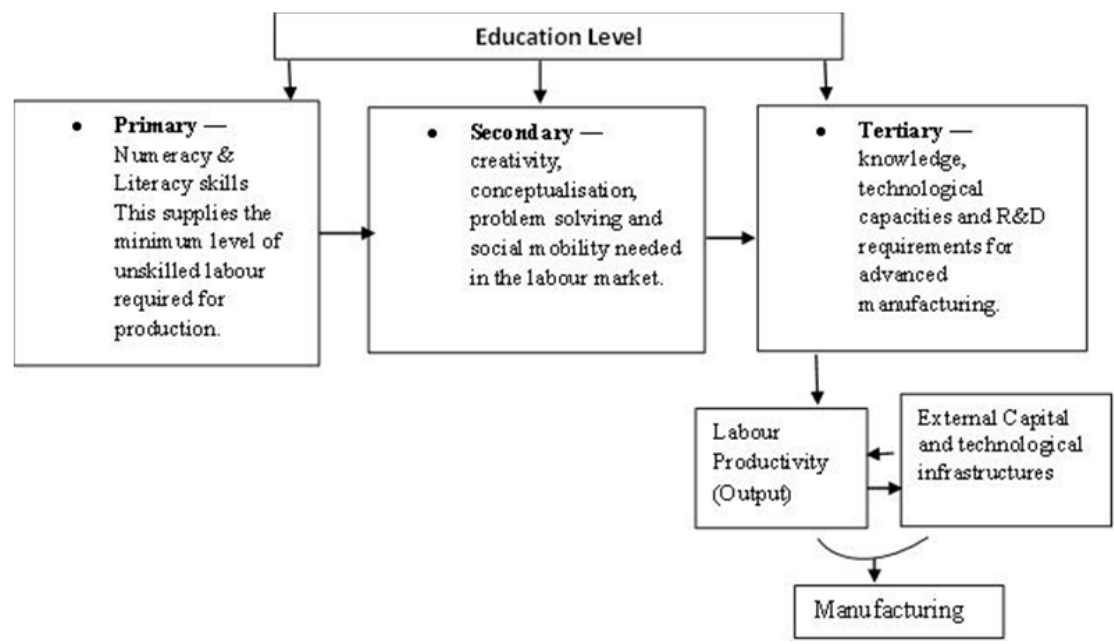

Figure 1: Education-Manufacturing Linkages adapted from UNECA (2015)

Source: Adapted from Anyanwu (2018)

\subsection{Model Specification}

Following the empirical studies from Chenery (1960), European Commission (2009a) and Anyanwu (2018) which undertake cross-country studies examining the effect of education, technology, population and income on the manufacturing, the model for this present evaluation takes the following form:

$\log M V A=\alpha_{0}+\alpha_{1} \log L A B P+\alpha_{2} \log X+\alpha_{3} \log X+u$

Where $\mathrm{Y}$ is income, $\mathrm{N}$ is population, $\mathrm{X}$ is a vector of other explanatory variables, and $\mathrm{u}$ is the random disturbance term. The explanatory variables adopted in extant studies such as Anyanwu (2018) and European Commission (2009a) include supply side and demand side indicators such as interest rate, degree of openness, technological variables and financial depth.

The explicit form of the model to be estimated is as follows:

$\log M V A=\log \beta_{0}+\beta_{1} \log L A B P+\beta_{2} \log G F C F++\beta_{3} \log F D E P T H++\beta_{4} \log O P N++\beta_{5} L I N T R+$ $\beta_{6} \log I C T G E X P++\beta_{7} \log I U T++\beta_{8} \log S I S++\beta_{9} \log M C S+u_{i}$

MVA is manufacturing output (captured by manufacturing value added, constant 2010 US\$); LABP is labour productivity (GDP per person employed), GFCF is gross fixed capital formation (constant 2010 US\$), FDEPTH is financial depth (Domestic credit to private sector by banks (\% of GDP)), OPN is degree of openness [ $\frac{\text { mport }+ \text { Export }}{G D P}$ (all in constant 2010 US\$)], LINTR is Lending interest rate (\%); ICTGEXP = ICT goods exports (\% of total goods exports), IUT is Individuals using 
the Internet (\% of population), SIS is secure internet servers (per 1 million people), MCS is mobile cellular subscription (per 100 people). It is important to note that IUTS, SIS and MCS are all measures of technology; GFCF, FDEPTH, OPN and LINTR are control variables.

\subsection{Estimation Technique}

In evaluating effect of labour productivity on manufacturing output, the study used a panel data of fifteen ECOWAS countries for the period 1990 to 2019. A static panel data analysis was adopted in order to control for the unobservable specific differences across the ECOWAS countries. The static panel analysis entails two specifications, namely, the fixed effect specification and the random effect specification. The former removes the effect of those time invariant characteristics from the predictor variables in order to access the predictors' net effect (Ogundipe, Alege and Ogundipe, 2015). It is assumed that factors within the entities impact or bias the predictor or outcome variables and needs to be controlled for. This is the basis for the assumption of correlation between the entity's error term and the predictor variables. The fixed effect model is represented as follow:

$Y_{i t}=\beta_{1} X_{1, i t}+\ldots . .+\beta_{k} X_{k, i t}+\alpha_{i}+u_{i t}$

$i=1, \ldots, n t=1, \ldots \ldots T . \beta_{1} \ldots \beta_{k}$ are the explanatory variables in the model, $Y$ is the dependent variable, $u$ is the error term. The $\alpha_{i}$ are entity specific intercepts that capture heterogeneities across entities.

The random effect, unlike the fixed effect, assumes that variation across entities is random and uncorrelated with the predictor or the explanatory variables in the model.

The random effect is represented as follow:

$Y_{i t}=\beta X_{i t}+\alpha+u_{i t}+\varepsilon_{i t}$

From the above, the entity's error term is not correlated with the predictors. The fixed effect and random effect outcome are mutually exclusive, there is need to decide which of the two models best fit and explain the economic phenomenon that is being described. In doing this, the Hausmann test was adopted in testing for the best and reliable model.

\subsection{Data Sources}

The data used in the empirical analysis were obtained from World Bank (2019) World Development Indicators (WDI). The description of the variables and their measurement is summarized in Table 1.

Table 1: Variables, their Definitions, Measurements and Sources

\begin{tabular}{|l|l|c|}
\hline Variables & Definition and Measurement & Data Source \\
\hline MVA & $\begin{array}{l}\text { Manufacturing refers to industries in the International Standard Industrial Classification } \\
\text { (ISIC), revision 3, divisions 15-37. MVA captures sectoral net output after aggregating } \\
\text { outputs minus intermediate inputs. It does not deduct degeneration/extinguishment of } \\
\text { natural resources and produced assets. Data is reflected in constant 2o1o U.S. dollars. }\end{array}$ & WDI (2019) \\
\hline LABP & $\begin{array}{l}\text { GDP per person employed is GDP divided by overall national employment. Converting } \\
\text { GDP to 2o11 constant international dollars through PPP rates is Purchasing power } \\
\text { parity (PPP) GDP. }\end{array}$ & WDI (2019) \\
\hline GFCF & $\begin{array}{l}\text { Average yearly growth of gross fixed capital formation based on constant local } \\
\text { currency. Aggregates are based on constant 2o1o U.S. dollars. }\end{array}$ & WDI (2019) \\
\hline FDEPTH & $\begin{array}{l}\text { Domestic credit to private sector by banks refers to financial aid (trade credits, } \\
\text { purchasing non-equity securities, loans and other receivables which enable repayment } \\
\text { claims (which might incorporate lending to public ventures in some nations). }\end{array}$ & WDI (2019) \\
\hline OPN & $\begin{array}{l}\text { This was calculated by the authors via adding imports with exports, then dividing their } \\
\text { sum by economic growth, all in constant 2o10 US\$. }\end{array}$ & WDI (2019) \\
\hline LINTR & $\begin{array}{l}\text { Lending rate entails the bank rate, usually determined by financing goals, credit } \\
\text { standing of borrowers and vary according to different economies. This typically } \\
\text { satisfies short- and medium-term funding necessities of private enterprises. }\end{array}$ & WDI (2019) \\
\hline
\end{tabular}




\begin{tabular}{|l|l|c|}
\hline Variables & Definition and Measurement & Data Source \\
\hline ICTGEXP & $\begin{array}{l}\text { ICT goods exports encompasses electronics, communication, peripheral and computer } \\
\text { equipment, alongside other information and technology products. }\end{array}$ & WDI (2019) \\
\hline IUT & $\begin{array}{l}\text { Internet users are persons with internet usage (through digital TV, games, mobile } \\
\text { phones, computer machineries, etc) in prior 3 months regardless of their geographical } \\
\text { setting (from any location). }\end{array}$ & WDI (2019) \\
\hline SIS & $\begin{array}{l}\text { This refers to the number of unique, publicly-trusted TLS/SSL certificates available in } \\
\text { the Netcraft Secure Server Survey. }\end{array}$ & WDI (2019) \\
\hline MCS & $\begin{array}{l}\text { This involves subscriptions to a public mobile telephone service (with voice } \\
\text { communications) that allows access to the PSTN using cellular technology. The indicator } \\
\text { includes (and is split into) the number of post-paid subscriptions, active prepaid accounts } \\
\text { within the last three months. It excludes USB modem, telemetry, radio paging, telepoint, } \\
\text { private trunked mobile radio, pubic mobile and personal data subscriptions. }\end{array}$ & WDI (2019) \\
\hline
\end{tabular}

Source: Authors' compilation (2019)

\subsection{Preliminary Analyses}

\subsubsection{Descriptive Statistics of Variables}

Table 2 presents the statistical description of the variables used in the model. The manufacturing value added has a mean of approximately three trillion U.S dollars, a minimum of 848,390 U.S dollars and a minimum of 44 million U.S dollars. The wide differential between the minimum and maximum values show that the performance of the manufacturing sector and its contribution to GDP differs significantly across ECOWAS economies. In the same vein, other variables also show this remarkable difference, the capital stock has a minimum value in negative of thirty million U.S dollars, a mean of 6 trillion U.S dollars and a maximum value of 70 trillion U.S dollars. The cost of capital is generally high in the sub-region with a mean of about $14 \%$ and a maximum of $62.8 \%$. The rate of technological adoption is also low compared to emerging markets in other regions; the average mobile phone subscription per 1,00o people in the sub-region is about 30 persons while average access to secured internet servers per 1,ooo people is about 17.1 persons. Finally, the statistics shows that on the average, ECOWAS economies are considerably open with a mean openness of about $68 \%$.

Table 2: Summary Statistics of Variales

\begin{tabular}{|c|c|c|c|c|c|c|c|c|c|c|}
\hline Var. & MVA & FDEPTH & GFCF & ICTGEXP & IUINT & LABP & LINTR & MCS & OPEN & SIS \\
\hline Mean & $3.29 \mathrm{E}+09$ & 14.38252 & $6.77 \mathrm{E}+09$ & 0.215159 & $5 \cdot 525084$ & 5804.873 & 14.40191 & $29.955^{2}$ & 0.678124 & 17.06066 \\
\hline Median & $2.88 \mathrm{E}+\mathrm{o} 8$ & 12.2822 & $1.19 E+09$ & 0.102241 & 1.248676 & 4691.788 & 13.1822 & 5.943535 & 0.579921 & 1.891768 \\
\hline Maximum & $4.45^{\mathrm{E}+10}$ & 65.27793 & $7.08 E+10$ & 2.485915 & 58.17137 & 19438.73 & 62.83333 & $139 \cdot 529$ & 2.078464 & 498.3752 \\
\hline Minimum & 848390 & 0.402581 & $-3 \cdot 7 \mathrm{E}+07$ & $5.28 \mathrm{E}-\mathrm{o} 6$ & o & $795 \cdot 707$ & $4 \cdot 736667$ & o & 0.188822 & 0.095965 \\
\hline Std. Dev. & $8.38 \mathrm{E}+09$ & $11.45^{252}$ & $1.62 \mathrm{E}+10$ & 0.350167 & 10.1151 & 3784.722 & 10.22473 & 39.22329 & 0.30699 & 57.09327 \\
\hline Skewness & 3.196946 & 2.056961 & 2.82549 & 3.704959 & 2.832239 & 1.514334 & 1.275171 & 1.092726 & 1.402993 & $5 \cdot 912442$ \\
\hline Kurtosis & 12.78975 & 8.483456 & $9 \cdot 32727$ & 19.18909 & 11.29346 & 5.020654 & 5.73182 & 2.914962 & 5.796583 & 44.07703 \\
\hline Jarque-Bera & 1669.136 & 820.4132 & 887.6044 & 2456.699 & 1500.408 & 240.2627 & $137 \cdot 343$ & 85.30457 & 189.641 & 9897.064 \\
\hline Probability & o & o & o & o & o & o & o & o & o & o \\
\hline Sum & $9.64 \mathrm{E}+11$ & 6026.277 & $2.00 E+12$ & 40.01955 & 1972.455 & 2525120 & 3398.852 & 12820.83 & 196.656 & 2217.886 \\
\hline Sum Sq.Dev. & $2.05 \mathrm{E}+22$ & 54824.92 & $7 \cdot 74 \mathrm{E}+22$ & 22.68418 & 36424.26 & $6.22 \mathrm{E}+09$ & 24568.09 & $656925 \cdot 3$ & 27.23618 & 420493.8 \\
\hline Observations & 293 & 419 & 296 & 186 & 357 & 435 & 236 & 428 & 290 & 130 \\
\hline
\end{tabular}

Source: Compiled by the Authors

\subsubsection{Multicollinearity test}

Table 3 presents the pairwise correlation test for the explanatory variables in the model. This is required to assess the extent of linear dependence among the explanatory variables, as its presence makes the unique influence of the explanatory variables non-deterministic. The evidence from the Table shows no serious problem of multicollinearity, the correlations were considered moderate. Though, some level of linear dependence occurs but theoretically it has been proven that economic variables cannot be void of 
some inter-relationships, its only becomes a problem, when the degree of correlation is near perfect.

Table 3: Correlation matrix

\begin{tabular}{|c|c|c|c|c|c|c|c|c|c|}
\hline Var. & FDEPTH & GFCF & ICTGEXP & IUINT & LABP & LINTR & MCS & OPEN & SIS \\
\hline FDEPTH & 1 & -0.26351 & 0.201818 & 0.543466 & 0.258722 & -0.20686 & 0.319097 & 0.38867 & 0.281827 \\
\hline GFCF & & 1 & -0.26187 & 0.267187 & 0.72554 & 0.526609 & -0.0466 & -0.39259 & 0.312784 \\
\hline ICTGEXP & & & 1 & 0.17162 & -0.04954 & -0.19537 & 0.046775 & 0.033322 & -0.05113 \\
\hline IUINT & & & & 1 & 0.70335 & 0.252144 & o. 577541 & -0.10565 & 0.59772 \\
\hline LABP & & & & & 1 & 0.483374 & 0.369896 & -0.35737 & 0.459688 \\
\hline LINTR & & & & & & 1 & 0.083307 & -0.10415 & 0.276221 \\
\hline MCS & & & & & & & 1 & 0.013713 & 0.177582 \\
\hline OPEN & & & & & & & & 1 & -0.07742 \\
\hline SIS & & & & & & & & & 1 \\
\hline
\end{tabular}

Source: Compiled by Authors

\section{Results and Discussion}

It is necessary to note that all variables were logged to restore normality and prevent heteroscedastic variation in the annual data. From the compiled panel result in Table 4, the Hausman test shows that the fixed effect (FE) model produced best and reliable result. The probability value of the Hausman indicates the rejection random model $5 \%$ significance level. Hence, the focus of interpretation is on the fixed effect model.

Table 4.1: Regression Result

\begin{tabular}{|c|c|c|c|c|c|c|c|}
\hline & (ols) & $(\mathrm{fe})$ & (re) & \multicolumn{4}{|c|}{ Controlling for technological variables } \\
\hline VARIABLES & Lnmva & lnmva & Lnmva & lnmva & lnmva & lnmva & Lnmva \\
\hline lnlabp & $\begin{array}{c}0.574^{* * *} \\
(0.123)\end{array}$ & $\begin{array}{c}0.364^{* * *} \\
(0.106)\end{array}$ & $\begin{array}{c}0.418^{* * *} \\
(0.119)\end{array}$ & $\begin{array}{l}0.473^{*} \\
(0.245)\end{array}$ & $\begin{array}{l}0.240 \\
(0.151)\end{array}$ & $\begin{array}{c}0.908^{* * *} \\
(0.292)\end{array}$ & $\begin{array}{l}0.441^{* *} \\
(0.145)\end{array}$ \\
\hline $\operatorname{lngfcf}$ & $\begin{array}{l}0.850^{* * *} \\
(0.0357)\end{array}$ & $\begin{array}{l}0.0901^{* *} \\
(0.0402)\end{array}$ & $\begin{array}{l}0.191^{* * *} \\
(0.0444)\end{array}$ & $\begin{array}{l}0.376^{* * *} \\
(0.0899)\end{array}$ & $\begin{array}{c}0.0858^{* *} \\
(0.0391)\end{array}$ & $\begin{array}{l}0.0526 \\
(0.102)\end{array}$ & $\begin{array}{l}0.146^{* * *} \\
(0.0549)\end{array}$ \\
\hline lnfdepth & $\begin{array}{l}-0.191^{*} \\
(0.105)\end{array}$ & $\begin{array}{l}0.235^{* * *} \\
(0.0515)\end{array}$ & $\begin{array}{l}0.161^{* * *} \\
\left(0.05^{88}\right)\end{array}$ & $\begin{array}{l}0.197^{*} \\
(0.106)\end{array}$ & $\begin{array}{l}0.189^{* * *} \\
(0.0565)\end{array}$ & $\begin{array}{c}0.155 \\
(0.129)\end{array}$ & $\begin{array}{c}0.176^{* *} \\
(0.0698)\end{array}$ \\
\hline lnopn & $\begin{array}{c}-0.905^{* * *} \\
(0.145)\end{array}$ & $\begin{array}{l}-0.216^{* * *} \\
(0.0710)\end{array}$ & $\begin{array}{c}-0.349^{* * *} \\
(0.0806)\end{array}$ & $\begin{array}{c}-0.474^{* * *} \\
(0.105)\end{array}$ & $\begin{array}{c}-0.212^{* * *} \\
(0.0711)\end{array}$ & $\begin{array}{c}-0.245^{* *} \\
(0.101)\end{array}$ & $\begin{array}{l}-0.231^{* * *} \\
(0.0766)\end{array}$ \\
\hline lintr & $\begin{array}{c}-0.0423^{* * *} \\
(0.00757)\end{array}$ & $\begin{array}{c}0.00329 \\
(0.00319)\end{array}$ & $\begin{array}{c}0.00163 \\
(0.00371)\end{array}$ & $\begin{array}{c}0.0190 \\
(0.0179)\end{array}$ & $\begin{array}{c}0.0159 \\
(0.0106)\end{array}$ & $\begin{array}{c}-0.0391 \\
(0.0344)\end{array}$ & $\begin{array}{l}0.00873 \\
(0.0102)\end{array}$ \\
\hline lnictgdexp & & & & $\begin{array}{l}0.00471 \\
(0.0158)\end{array}$ & & & \\
\hline lniut & & & & & $\begin{array}{c}0.0464^{* *} \\
(0.0191)\end{array}$ & & \\
\hline lnsis & & & & & & $\begin{array}{c}0.0755^{* * *} \\
(0.0194)\end{array}$ & \\
\hline $\operatorname{lnm} c s$ & & & & & & & $\begin{array}{c}0.0165 \\
(0.0166)\end{array}$ \\
\hline Constant & $\begin{array}{c}-2.149^{* * *} \\
(0.680)\end{array}$ & $\begin{array}{c}14.41^{* * *} \\
(1.096)\end{array}$ & $\begin{array}{c}11.70^{* * *} \\
(1.201)\end{array}$ & $\begin{array}{c}7 \cdot 573^{* * *} \\
(2.151)\end{array}$ & $\begin{array}{c}15.47^{* * *} \\
(1.466)\end{array}$ & $\begin{array}{l}11.14^{* * *} \\
(2.339)\end{array}$ & $\begin{array}{c}13.54^{* * *} \\
(1.434)\end{array}$ \\
\hline Hausman (p-value) & & 0.0000 & & 0.0097 & 0.0000 & 0.0000 & 0.0000 \\
\hline Observations & 160 & 160 & 160 & 92 & 148 & 79 & 147 \\
\hline R-squared & 0.916 & 0.431 & & 0.545 & 0.525 & 0.580 & 0.485 \\
\hline Number of id & & 12 & 12 & 10 & 12 & 12 & 12 \\
\hline
\end{tabular}

Standard errors in parentheses

Source: Computed by Authors 
Following the fixed effect model, labour productivity is significant and exerts an elastic influence on MVA. The evidence shows that a $1 \%$ increase in labour productivity results in $36.4 \%$ increase in manufacturing output. This implies that enhancing labour performance positively impacts output. The magnitude of the relationship depicts the weak response of domestic output in the ECOWAS economies. This weak magnitude could be attributed to the fact that ECOWAS economies are plagued with large number of low-skilled workers. Given the skill requirement of the sector at the early stage, this shortcoming can be very detrimental to the region as evidenced over the years. It's thus necessary for the sub-region economies to develop human capital and skills towards expanding the manufacturing sector and attaining domestic sufficiency in the ECOWAS economies.

In the same vein, capital stock significantly and positively affects MVA. A $100 \%$ increase in capital results in about $9 \%$ increase in the manufacturing sector. Again, this affirms theoretical postulations of the essence of capital formation for sustained growth. However, the rather low level of capital reflects that ECOWAS need in boosting investment in infrastructural amenities despite slight regional technological improvement. For instance, bad roads and electricity supply are major constraining factors to optimising technology and capital (e.g. machineries cannot work without reliable power supply). An example is the deficient power and transport facilities in the sub-region, unavailable power hinders businesses progress and expansion and bad road infrastructure is an impediment to smooth transportation of commodities from factory to the consumers.

Similarly, financial depth is significant and exerts an elastic impact on MVA. A $100 \%$ increase in financial depth results in about $23.5 \%$ rise in MVA. This confirms with the apriori expectation it thus implies that strong financial system enhances MVA, as the credits are easily channelled to the real sector for growth and expansion given that it is expected to induce deepness of the financial sector and overall labour productivity. Undeniably, a sound financial sector will be immensely beneficial to producers and manufacturing firms. The degree of openness exerts a significant inelastic influence on MVA. The evidence shows that a change in openness results in a less than proportional change in MVA by about $21.6 \%$. This aligns with theory as it indicates that countries should be careful in the magnitude to which their borders are opened, as this is detrimental to local industries and production. Furthermore, this triggers susceptibility to dump foreign goods into ECOWAS economies, since the economies are yet to fully explore, diversify and leverage on available resources and infrastructures for maximum production of quality items. More so, the results show that lending interest rate is an important determinant of MVA. This is in direct contrast with theory, probably because many start-ups and Small enterprises are finding alternative sources of funds (such as crowdfunding and angel investors) due to high cost of capital.

Furthermore, when the model was controlled for technological variables, the nexus between MVA and labour productivity changed considerably. Specifically, the indicators of individuals using internet and secured servers (sis), and mobile phone communication subscribers (mcs) stimulated the impact of labour productivity on MVA. The magnitude impact of labour productivity on MVA surged from 0.361 to 0.908 and 0.441 following the control for individuals using internet and secured servers and mobile phone communication respectively. Similar evidence was found by Oluwatobi, Olurinola, Alege, \& Ogundipe, (2018). This implies that the availability of technology and its utilisation aided the influence of labour contribution on MVA in the ECOWAS sub-region.

\section{Conclusion and Policy Recommendation}

This study assesses the impact of labour productivity on the manufacturing output of ECOWAS countries; in addition, we considered the influence technology in the labour productivity and manufacturing output nexus in the sub-region. The study adopted a human capital theoretical based and the empirical estimation was performed using a panel data analysis. The data used for the empirical test were obtained from the World Bank 2019 Development Indicators for the period 1990 to 2019. The study found that manufacturing value added responded positively and significantly to labour productivity; however, the impact was greater when technological utilisation was controlled 
for. Specifically, the indicator of internet and secured servers users, and mobile phone subscribers significantly stimulates the relationship between labour productivity and manufacturing value-added in the ECOWAS sub-region. Thus, for sustained efficiency of labour force, there is need for increased training (on-the-job and vocational training) for both skilled and unskilled workers and provision technological facilities; this will ensure substantial improvement in output and productivity levels of West Africa economies.

\section{References}

Acemoglu, D. (2003). Patterns of skill premia. Review of Economic Studies, 7o(2), 199-230.

Adejumo, A. V. (2013). Foreign direct investments and manufacturing sector performance in Nigeria (1970-2009). Australian Journal of Business and Management Research, 3(4), 39-56.

Alege, P. O and Ogundipe, A. A. (2014). Foreign Direct Investment and Economic Growth in ECOWAS: A System GMM Approach. Covenant Journal of Business and Social Sciences 5(1)

Amin, M. \& Mattoo, A. (2008). Human capital and the changing structure of the Indian economy. World Bank Policy Research Working Paper, No. 4576.

Adenikinju, A., \& Alaba, O. (2005). EU-ACP Economic Partnership Agreements: Implication for Trade and Development in West Africa. TPRTP, University of Ibadan, Nigeria.

Adeyemi, P. A., \& Olufemi, O. B. (2016). The determinants of capacity utilization in the Nigerian manufacturing sector. Journal of Economics and Sustainable Development, 7(5), 20-31.

Afolabi, A., \& Laseinde, O. T. (2020). Manufacturing Sector Performance and Economic Growth in Nigeria. Journal of Physics: conference series 1378(2020) 032067

Agenor-Pierre R. (1995). International Competitiveness and External Trade Performance. IMF Working Paper.

Anyanwu, J.C., 2017. Manufacturing value added development in North Africa: Analysis of key drivers. Asian Development Policy Review, 5(4), 281-298.

Anyanwu, J. C. (2018). Does Human Capital Matter in Manufacturing Value Added Development in Africa. Asian Journal of Economic Modelling, 6(3), 294-317.

Anyanwu, J. C. \& Kponnou, M. (2017). Accelerating agro-manufacturing to feed Africa. African Development Review, $29\left(\mathrm{~S}_{2}\right)$, 78-95.

Asaleye, A. J., Olurinola, I. O., Oloni, E. F., \& Ogunjobi, O. (2017). Productivity Growth, Wages and Employment Nexus: Evidence from Nigeria. Journal of Applied Economic Sciences, 12(5).

Bartel, A.P. \& Lichtenberg, F. R. (1987). The comparative advantage of educated workers in implementing new technology. Review of Economics \& Statistics, 69(1), 1-11.

Becker, G. (1998). Human capital and poverty. Religion E Liberty, 8(1), 5-7.

Benhabib, J. \& Spiegel, M. M. (1994). The role of human capital in economic development. Journal of Monetary Economics, 34(2), 143-174.

Benhabib, J. \& Spiegel, M. M. (2005). Human capital and technology diffusion. In Aghion, P. and Durlauf, S. (Eds.), The handbook of economic growth. North Holland, Amsterdam.

Bigsten, A. (2000). Rates of return on physical and human capital in Africa's manufacturing sector. Economic Development and Cultural Change, 48(4), 801-827.

Bircan, C., T. Brück \& Vothknecht, M. (2010). Violent conflict and inequality. IZA Discussion Paper No. 4990.

Boddy-Evans, A. (2019). What is the Economic Community of West African States (ECOWAS)? Thought Co.

Caselli, F. \& Coleman, J.W.I. (2006). The world technology frontier. American Economic Review, 96(3), 499-522.

Bollou, F., \& Ngwenyama, O. (2008). Are ICT investments paying off in Africa? An analysis of total factor productivity in six West African countries from 1995 to 2002. Information Technology for Development, 14(4), 294-307.

Cantore, N., Clara, M., Lavopa, A., \& Soare, C. (2017). Manufacturing as an engine of growth: Which is the best fuel? Structural Change and Economic Dynamics, 42, 56-66.

Capirossi, J. (2002). The paradox of Solow: Myth or reality.

Chenery, H. B. (1960). Patterns of industrial growth. American Economic Review, 50(4), 624-654.

Chete, L. N., Adeoti, J. O., Adeyinka, F. M. \& Ogundele, O. (2014). Industrial development and growth in Nigeria: Lessons and challenges (No. 2014/019).

Ciccone, A. \& Papaioannou, E. (2009). Human capital, the structure of production and growth. Review of Economics and Statistics, 9(1), 66-82.

De Vries, G. J. (2010). Small retailers in Brazil: Are formal firms really more productive? The Journal of Development Studies, 46(8), 1345-1366. 
Delivani 1, E. (1992). A Kaldorian approach to Greek economic growth: a comment. Applied Economics, 24(12), 1357-1359.

European Commission (2009a). European competitiveness report 2008. Luxembourg: European Commission.

Frankema, E. (2015). Labour-intensive industrialization in global history: a review essay. Economic History of Developing Regions, 30(1), 44-67.

Haile, F. (2018). Structural Change in West Africa: A Tale of Gain and Loss. The World Bank.

Isaksson, A. (2010). Public capital, infrastructure and industrial development. Research and Statistics Branch Working Paper, 15/2009, UNIDO, Vienna. pp: 59.

Levchenko, A., (2007). Institutional quality and trade. Review of Economic Studies, 74(3), 791-819.

Keho, Y. (2018). Manufacturing and Economic Growth in ECOWAS Countries: A Test of Kaldor's First Law. Modern Economy, 9(5).

Meyer, D. F., \& Mc Camel, R. T. (2017). A Time Series Analysis of the Relationship between Manufacturing, Economic Growth and Employment in South Africa. Journal of Advanced Research in Law and Economics, $8(4(26)), 1206-1218$.

Nattrass, N., \& Seekings, J. (2012). Differentiation within the South African clothing industry: Implications for wage setting and employment.

Nunn, N. (2007). Relationship-specificity, incomplete contracts and the pattern of trade. Quarterly Journal of Economics, 122(2), 569-6oo.

Ola-David, O., Amoo, E. O., Olurinola, O., \& Fadayomi, T. (2013). Migration Prospects of Youths Employed in Nigerian Cities. Available at SSRN 2513137.

Oluwatobi, S., Olurinola, I., Alege, P., \& Ogundipe, A. (2018). Knowledge-driven economic growth: the case of Sub-Saharan Africa. Contemporary Social Science, 1-20.

Ossadzifo, K. (2018). Impact of telecommunications market liberalization on labor productivity in economic community of west African States. Journal of Social Economics Research, 5(2), 63-74.

Onakoya, A. B. (2018). Macroeconomic Dynamics and the Manufacturing Output in Nigeria. Mediterranean Journal of Social Sciences, 9(2), 43-54.

Rispal, C. (2009). Does innovation and the knowledge economy promote growth?

Rosendahl, C. (2010). Industrial policy in Namibia.

Schultz, T. W. (1975). The value of the ability to deal with disequilibria. Journal of Economic Literature, 13(3), 827846.

Sejkora, J., \& Sankot, O. (2017). Comparative advantage, economic structure and growth: The case of Senegal. South African Journal of Economic and Management Sciences, 20(1), 1-9.

Solow, R. M. (1987). We'd better watch out. New York Times Book Review 36, July 12.

Szirmai, A. (2009). Is Manufacturing still the main engine of growth in Developing countries, accessed o3-06-2019 available @ https://wider.unu.edu/publication/manufacturing-still-main-engine-growth-developingcountries

Triplett, J. E., \& Bosworth, B. (2003). Productivity measurement issues in services industries: Baumol's disease has been cured. Economic Policy Review, 9(3), 22-33.

Tsoku, J. T., Mosikari, T. J., Xaba, D., \& Modise, T. (2017). An Analysis of the Relationship between Manufacturing Growth and Economic Growth in South Africa: A Cointegration Approach. World Academy of Science, Engineering and Technology, International Journal of Social, Behavioral, Educational, Economic, Business and Industrial Engineering, 11(2), 414-419.

UNIDO (2015). Industrial development report 2016: The role of technology and innovation in inclusive and sustainable industrial development. Vienna: UNIDO.

Welch, F. (1970). Education in production. Journal of Political Economy, 78(1), 35-59.

West Africa Economic Outlook (2018). Macroeconomic developments and poverty, inequality, and employment Labour markets and jobs. African Development Bank Group. 